\title{
Transport of Neutral and Dibasic Amino Acids by Human Leukocytes: Absence of Defect in Cystinuria *
}

\author{
Leon E. Rosenberg † ANd Sylvia Downing
}

(From the Metabolism Service, National Cancer Institute, Bethesda, Md.)

The mechanisms by which cells transport and accumulate vital metabolites such as cations, anions, sugars, and amino acids have come under careful scrutiny during recent years. Although this subject is of great interest to investigators of human physiology and disease, the lack of suitable and accessible human cell preparations for in vitro study has made progress in this field difficult. During the past decade methods have been devised for the isolation of human leukocytes from peripheral blood, and such cells have been used to study a wide range of physiologic and biochemical mechanisms (1). To date, however, leukocytes have been used sparingly in studies of ion or nonelectrolyte transport.

Several investigators (2-4) have reported that the free amino acid content of normal and leukemic leukocytes far exceeds that of plasma, suggesting that these cells maintain "uphill" concentration gradients in vivo. Yunis, Arimura, and Kipnis (5) showed that leukemic lymphocytes and granulocytes can accumulate a variety of neutral amino acids in vitro by processes that are sodium dependent and ouabain sensitive. It is well known, however, that the metabolism of leukemic cells differs in many significant ways from that of normal leukocytes (6), and, therefore, it was deemed important to investigate transport and metabolism of amino acids by normal leukocytes.

Recent in vitro studies have demonstrated defective transport of lysine and arginine by human gut and kidney in cystinuria (7-9). Cystine uptake was also defective in intestinal mucosa $(8,9)$ but, surprisingly, not in kidney cortex from cystinuric subjects (7). To characterize the transport systems for the dibasic amino acids and cystine

\footnotetext{
* Submitted for publication January 11, 1965; accepted April 28, 1965.

$\dagger$ Address requests for reprints to Dr. Leon E. Rosenberg, Dept. of Medicine, Yale University School of Medicine, Yale-New Haven Hospital, New Haven, Conn.
}

in a third human tissue and to determine if defects in amino acid transport exist in tissues other than gut and kidney, the present studies with isolated peripheral leukocytes were undertaken. A portion of these findings was previously reported in abstract form (10).

\section{Methods}

Subjects studied. Sixty normal male and female volunteers, ranging in age from 20 to 45 years, and nine patients with cystinuria, 21 to 37 years of age, served as blood donors for these experiments. Each study was performed with cells from only one subject. All experiments were repeated with leukocytes from two to four subjects, and the data to be presented represent either mean values from several experiments or representative results from a single study.

Leukocyte isolation. Leukocytes were prepared from 100 - to $500-\mathrm{ml}$ quantities of fresh, whole, heparinized blood. The blood, obtained after an overnight fast, was collected in plastic bags containing $5 \mathrm{U}$ of heparin per $\mathrm{ml}$ of blood. Initial separation of leukocytes from erythrocytes was undertaken by dextran sedimentation, based on techniques of Skoog and Beck (11) as modified by Fallon and co-workers (12). Equal volumes of blood and $6 \%$ dextran in isotonic saline were mixed in plastic bags and allowed to sediment in the upright position for 45 minutes at $4^{\circ} \mathrm{C}$. The supernatant containing leukocytes, platelets, variable numbers of erythrocytes, and plasma was then expressed into a second plastic bag and centrifuged at $170 \mathrm{~g}$ for 10 minutes at $4^{\circ} \mathrm{C}$. The supernatant was discarded and the cell button mixed with 250 $\mathrm{ml}$ of $5 \%$ dextrose in distilled water per $500 \mathrm{ml}$ blood to remove any remaining plasma and dextran. This suspension was transferred to siliconized $50-\mathrm{ml}$ centrifuge tubes and spun at $70 \mathrm{~g}$ for 10 minutes at $4^{\circ} \mathrm{C}$. After discarding the supernatant, the cell button was subjected to hypotonic lysis to remove remaining erythrocytes according to the method of Fallon and co-workers (12). The leukocytes were separated from the hemolysate by centrifugation at $70 \mathrm{~g}$ for 10 minutes at $4^{\circ} \mathrm{C}$, followed by aspiration of red cell ghosts from the surface of the leukocyte layer. Hypotonic lysis was then repeated yielding a yellow-green button of leukocytes that were suspended in the incubation medium desired for the experiment. Since significant clumping of leukocytes occurred regularly during initial studies and prevented the preparation of uniform leukocyte suspensions, $20 \mathrm{U}$ of strep- 
tokinase and $5 \mathrm{U}$ of streptodornase were added per $\mathrm{ml}$ of cell suspension at each step of the isolation procedure, after initial dextran sedimentation. This step obviated any further problem with clumping. All glassware used in isolation or incubation of leukocytes was siliconized.

Leukocyte incubation. Except where stated to the contrary, leukocytes were suspended in modified KrebsRinger bicarbonate buffer ( $\mathrm{pH}$ 7.4) containing the following concentrations of cations and anions ( $\mathrm{mEq}$ per L) : $\mathrm{Na}^{+}, 108 ;$ Tris ${ }^{+}, 36 ; \mathrm{K}^{+}, 7.2 ; \mathrm{Ca}^{++}, 5.1 ; \mathrm{Mg}^{++}, 2.4$; $\mathrm{Cl}^{-}, 130$; $\mathrm{HPO}_{-}^{-}, 1.2$; and $\mathrm{HCO}_{3}^{-}, 25$. The Tris- $\mathrm{HCl}$ buffer ( $\mathrm{pH} 7.4$ ) was substituted for a portion of the sodium chloride ( $36 \mathrm{mEq}$ per $\mathrm{L}$ ) usually used in KrebsRinger buffer to control $\mathrm{pH}$ and maintain isotonicity. Tris- $\mathrm{HCl}$ was also substituted for $\mathrm{NaCl}$ in an equimolar fashion in studies designed to determine influence of changing medium $\mathrm{Na}^{+}$concentration.

Leukocyte suspensions were mixed thoroughly by repeatedly drawing the cells in and out of a siliconized pipette and were then transferred to 25-ml Erlenmeyer flasks and preincubated in an atmosphere of $95 \% \mathrm{O}_{2}-5 \%$ $\mathrm{CO}_{2}$ for 3 to 6 minutes at $37^{\circ} \mathrm{C}$ in a Dubnoff metabolic shaker. The flasks were then removed from the shaker, and labeled amino acids were added, after which the flasks were reincubated as before for periods ranging from 2 to 120 minutes. In most experiments $2.5 \mathrm{ml}$ of leukocyte suspension was placed in each flask. In studies of the time course of amino acid uptake, several samples of suspension were withdrawn from the same flask, and in these studies up to $7.5 \mathrm{ml}$ of suspension was incubated in a single flask.

The incubation was terminated by pipetting duplicate $1.0-\mathrm{ml}$ samples of leukocyte suspension into precooled $\mathrm{McNaught}$ calibrated centrifuge tubes at $4^{\circ} \mathrm{C}$. (Amino acid uptake was negligible at this temperature, and intracellular amino acid content was virtually unchanged for as long as 30 minutes at $4^{\circ} \mathrm{C}$.) The tubes were centrifuged at $1,800 \mathrm{~g}$ for 15 minutes at $4^{\circ} \mathrm{C}$ in a refrigerated Servall centrifuge, yielding a well-packed cell layer and a clear supernatant. After removing the supernatant medium, the surface of the cell pellet and sides of the tube were washed twice with cold $5 \%$ dextrose solution. The packed cell pellet volume (leukocrit) was recorded, and the cells were then mixed with $1.5 \mathrm{ml}$ of distilled water and boiled for 5 minutes. The cell pellet was then broken up by drawing the cells into a syringe through a 3 -inch, no. 13 gauge needle and then forcing them out through a no. 25 gauge needle. This procedure was repeated to insure rupture of all cells, after which the cell debris was spun down at $1,450 \mathrm{~g}$ for 15 minutes at room temperature and the supernatant analyzed for labeled amino acid content. Initially, the cell debris supernatant was prepared with either boiling water or acetic acid $(0.008 \mathrm{M})$ precipitation techniques. Since results with these two methods were in very good agreement, the boiling water technique was used for all future work. When incorporation of amino acids into tissue protein was being studied as well as amino acid uptake, the cell debris was taken up in $5 \%$ trichloroacetic acid, and the isotopically labeled tissue protein prepared and counted according to previously described techniques $(13,14)$.

Radioisotopic analyses. In studies of amino acid uptake, radioactivity was assessed by counting $0.2 \mathrm{ml}$ of the incubation medium or aqueous cell debris supernatant in a liquid scintillation spectrometer according to techniques described previously (15). Additional samples of the aqueous cell supernatant were analyzed by paper chromatography by a single dimension, descending system in a solvent of butanol:acetic acid: water $(4: 1: 2)$. The chromatograms were then cut and scanned for radioactivity with a double-window, gas-flow strip counter with an efficiency of approximately $15 \%$ for $\mathrm{C}^{\mathbf{1 4}}$. In each case, greater than $95 \%$ of the recovered radioactivity migrated with an appropriate $R_{f}$ for the amino acid used as substrate.

Calculation of the distribution ratio. The distribution ratio, defined as the ratio of counts per minute per milliliter intracellular fluid $\left(C_{1}\right)$ to the counts per minute per milliliter medium $\left(\mathrm{C}_{m}\right)$, was used in these studies as a measure of intracellular amino acid accumulation. It is assumed that ratios greater than unity for neutral amino acids indicate concentration against a chemical gradient either by "active" transport mechanisms or exchange diffusion. It is further assumed that distribution ratios of one or less can be explained by nonenergy-requiring processes conforming to the laws of exchange or physical diffusion, although they cannot, by themselves, exclude energy-linked passage. To determine the distribution ratio, the $C_{m}$ was assayed directly, and the $C_{1}$ was derived from the following expression:

$$
C_{i}=\frac{R_{t}-\left(C_{m} \times V_{e}\right)}{V_{t}-V_{t}},
$$

where $C_{1}$ is the labeled amino acid concentration per milliliter of intracellular water, $R_{t}$ the net radioactivity (counts per minute) of the packed cell pellet, $\mathrm{C}_{m}$ the labeled amino acid concentration per milliliter incubation medium, $V_{e}$ the trapped extracellular fluid volume, and $V_{t}$ the total cell pellet fluid volume. V. was estimated with inulin- $\mathrm{C}^{\mathbf{1 4}}$ and may be expressed either in milliliters or in per cent of the packed cell volume. The total cell pellet fluid volume $V_{t}$ was determined by the difference in weight of the packed cell pellet after incubation and after drying in an oven for 24 hours at $105^{\circ} \mathrm{C}$. Statistical analysis was performed by Student's $t$ test.

Materials. Dextran ${ }^{1}$ (average mol wt, 188,000) was autoclaved after being dissolved in isotonic sodium chloride solution. Streptokinase-streptodornase (Varidase) ${ }^{2}$ was added to the leukocyte suspension in a concentration of $10 \mathrm{U}$ per $\mathrm{ml}$ of cell preparation. Sodium cyanide, sodium fluoride, iodoacetamide, and 2,4-dinitrophenol were obtained commercially. ${ }^{3}$

L-Alanine-U-C ${ }^{14}$ (SA 125 mc per mmole), L-lysine-U$\mathrm{C}^{14}$ (SA $146 \mathrm{mc}$ per mmole), glycine-2-C ${ }^{14}$ (SA $3.3 \mathrm{mc}$ per mmole), L-methionine-methyl-C ${ }^{14}$ (SA $14.9 \mathrm{mc}$ per

\footnotetext{
1 Pharmachem Corp., Bethlehem, $\mathrm{Pa}$.

2 Lederle Laboratories, Pearl River, N. Y.

${ }^{3}$ Eastman Chemical Co., Rochester, N. Y.
} 


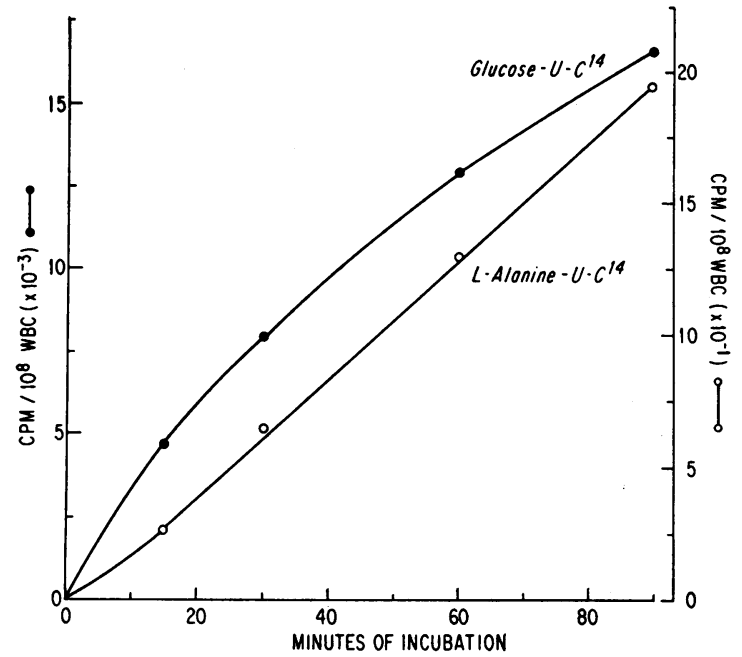

Fig. 1. $\mathrm{C}^{14} \mathrm{O}_{2}$ EVolUtion FROM D-GLUCOSE-U-C $\mathrm{C}^{14}$ OR L-ALANINE-U-C ${ }^{14}$. Note the difference in scale for results with glucose (left ordinate) and alanine (right ordinate). $\mathrm{D}$-Glucose- $\mathrm{C}^{\mathbf{1 4}}$ was present in tracer quantities, whereas $\mathrm{L}$-alanine concentration was 0.1 mmole per $\mathrm{L}$.

mmole), 1-amino cyclopentane 1-carboxylic acid-carboxyl$\mathrm{C}^{14}$ or ACPC (SA $26 \mathrm{mc}$ per mmole), and L-arginine-U$\mathrm{C}^{14}$ (SA $135 \mathrm{mc}$ per mmole) were obtained commercially.4 Alpha amino isobutyric acid-1-C ${ }^{14}$ or $\mathrm{AIB}^{5}$ (SA $19 \mathrm{mc}$ per mmole), L-histidine-U-C ${ }^{14}{ }^{6}$ (SA $1.06 \mathrm{mc}$ per mmole), D-glucose-U-C ${ }^{14} 7$ (SA 0.3 mc per mmole), L-cystine-S ${ }^{36} 7$ (SA $9.5 \mathrm{mc}$ per mmole), and inulin-carboxyl-C 14 (SA $2.1 \mathrm{mc}$ per $\mathrm{mg}$ and average mol wt of 3,000 to 4,000 ) were also obtained commercially. Each of the labeled amino acids was chromatographed on paper with a descending butanol: acetic acid: water $(4: 1: 2)$ system and was pure. The concentration of amino acids used in these studies ranged from 0.04 to 0.10 mmoles per $L$, values that approach the normal fasting plasma concentrations in man. Total radioactivity per $\mathrm{ml}$ of leukocyte suspension ranged from 0.1 to $0.2 \mu \mathrm{c}$.

\section{Results}

Morphologic and physiologic properties of isolated leukocytes. Leukocyte counts were obtained on whole blood and on the final leukocyte suspensions before incubation in 15 experiments. Leukocyte recovery ranged from 11.1 to $37.7 \%$ with a mean of $23.7 \%$. The packed cell volume of leukocytes per milliliter of cell suspension ranged from 4.5 to $10.8 \%$ with a mean of $6.5 \%$. The number

4 New England Nuclear Corp., Boston, Mass.

${ }^{5}$ Isotope Specialties Co., Burbank, Calif.

' Volk Radiochemical Corp., Chicago, Ill.

${ }^{7}$ Schwarz Bioresearch, Mt. Vernon, N. Y.

8 New England Nuclear Corp., Boston, Mass. of leukocytes necessary to yield $1 \mu$ of packed cells averaged $6.6 \times 10^{6}$ cells with a range of 4.1 to 9.7 $\times 10^{6}$. Smears of the leukocyte suspensions, stained by the Giemsa method, were examined by light microscopy. These smears revealed virtually no red cells and only few platelets. Leukocyte morphology and differential count did not differ significantly from whole blood smears. Furthermore, staining of leukocyte preparations with $0.025 \%$ trypan blue, a dye known to stain only nonviable cells (16), indicated that fewer than $5 \%$ of the cells were permeable to this substance.

Metabolic activity of the isolated leukocytes was demonstrated in three ways. These cells oxidized glucose- $\mathrm{C}^{14}$ and L-alanine- $\mathrm{C}^{14}$ to $\mathrm{C}^{14} \mathrm{O}_{2}$ throughout 90-minute incubation studies (Figure 1) and incorporated $\mathrm{C}^{14}$-labeled L-alanine and L-lysine into trichloroacetic acid precipitable tissue proteins during 45-minute studies (Figure 2). Intracellular $\mathrm{Na}^{+}$and $\mathrm{K}^{+}$concentrations were determined to evaluate the membrane cation transport mechanism (or "pump"). As noted in Table I, the intracellular $\mathrm{Na}^{+}$concentration was distinctly elevated before incubation, suggesting that the cells had imbibed $\mathrm{Na}^{+}$and lost $\mathrm{K}^{+}$during leukocyte preparation at $4^{\circ} \mathrm{C}$. However, when the cells were incubated at $37^{\circ} \mathrm{C}$ in a medium containing $108 \mathrm{mEq}$ per $\mathrm{L} \mathrm{Na}^{+}$and $7.2 \mathrm{mEq}$ per $\mathrm{L} \mathrm{K}^{+}$, intracellular $\mathrm{Na}^{+}$concentrations fell while cell $\mathrm{K}^{+}$rosefindings expected in the presence of a functioning cation pump mechanism.

Estimation of total water and trapped extracellular space. Total tissue water and trapped inulin- $\mathrm{C}^{14}$ space were measured in leukocytes prepared from 15 subjects and the following values

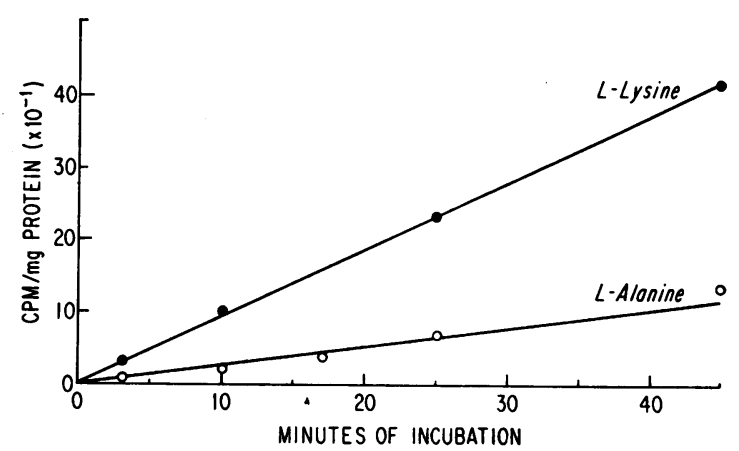

Fig. 2. INCORPORATION OF L-LYSINE-C ${ }^{14}$ AND L-ALANINE-C ${ }^{14}$ INTO LEUKOCYTE TISSUE PROTEIN. The concentrations of $\mathrm{L}$-lysine and $\mathrm{L}$-alanine in these studies were 0.05 mmole per $\mathrm{L}$ and 0.10 mmole per $\mathrm{L}$, respectively. 
TABLE I

Changes in leukocyte $\mathrm{Na}^{+}$and $\mathrm{K}^{+}$ during incubation*

\begin{tabular}{|c|c|c|}
\hline \multirow{2}{*}{$\begin{array}{l}\text { Duration of } \\
\text { incubation }\end{array}$} & \multicolumn{2}{|c|}{ Cation concentration } \\
\hline & $\mathrm{Na}^{+}$ & $\mathrm{K}^{+}$ \\
\hline minutes & \multicolumn{2}{|c|}{$m E q / L$ cell water } \\
\hline $\begin{array}{r}0 \\
3 \\
10 \\
17 \\
25 \\
45\end{array}$ & $\begin{array}{r}74.1 \\
104.0 \\
63.8 \\
55.4 \\
43.7 \\
39.5\end{array}$ & $\begin{array}{l}137.5 \\
156.7 \\
160.5 \\
157.0 \\
163.0 \\
166.0\end{array}$ \\
\hline
\end{tabular}

* Leukocytes were incubated in Krebs-Ringer-Tris buffer $\left(\mathrm{Na}^{+}, 108 \mathrm{mEq}\right.$ per L) at $\mathrm{pH} 7.4$ at $37^{\circ} \mathrm{C}$. Zero time samples were taken immediately before incubation, with the suspension at $4^{\circ} \mathrm{C}$. The results represent mean of duplicate observations from three subjects.

obtained (mean $\pm 1 \mathrm{SD}$ ): total tissue water, $84.5 \pm 2.5 \%$ of packed cell volume; inulin space, $42.3 \pm 6.0 \%$ of packed cell volume. These values, which agree well with data reported by Eisen, Kern, Newton, and Helmreich (17) using isolated lymph node cells, were used in all subsequent experiments.

Uptake of amino acids. As shown in Table II, alanine, histidine, methionine, lysine, arginine, and the nonmetabolizable, model amino acid ACPC (18) were accumulated by normal leukocytes against chemical gradients during 25-minute incubation studies. In contrast, glycine, glutamic acid, and a second model amino acid, AIB, were not concentrated intracellularly in repeated studies. Cystine uptake was variable. Distribution ratios of two were noted in some studies (Figure 3), but

TABLE II

Uptake of amino acids by normal human leukocytes*

\begin{tabular}{lcrrr}
\hline \hline & & \multicolumn{2}{c}{ Radioactivity } & \\
\cline { 4 - 5 } \multicolumn{1}{c}{$\begin{array}{c}\text { Medium } \\
\text { Amino acid }\end{array}$} & $\begin{array}{c}\text { concen- } \\
\text { tration }\end{array}$ & Medium & $\begin{array}{c}\text { Intracellu- } \\
\text { lar fluid }\end{array}$ & $\begin{array}{c}\text { Distri- } \\
\text { bution } \\
\text { ratio }\end{array}$ \\
\hline L-Alanine & $m M$ & \multicolumn{2}{c}{$c p m / m l$} & \\
L-Histidine & 0.10 & 63,380 & 380,280 & 6.0 \\
L-Methionine & 0.04 & 436,690 & $1,572,084$ & 3.6 \\
L-Lysine & 0.05 & 97,390 & 769,380 & 7.9 \\
L-Arginine & 0.05 & 147,320 & 486,160 & 3.3 \\
ACPC & 0.06 & 82,606 & 330,424 & 4.0 \\
Glycine & 0.07 & 210,450 & 673,440 & 3.2 \\
L-Glutamic acid & 0.05 & 110,900 & 113,100 & 1.0 \\
AIB & 0.07 & 119,330 & 28,160 & 0.2 \\
& 0.06 & 55,990 & 52,070 & 0.9
\end{tabular}

* All suspensions were incubated for 25 minutes in modified KrebsRinger-Tris bicarbonate buffer, pH 7.4 at $37^{\circ} \mathrm{C}$. Values represent the mean of duplicate observations in representative experiments. Uptake of each of the above amino acids was measured in leukocytes from at least three normal subjects. ACPC $=1$-amino cyclopentane 1-carboxylic acid-carboxyl-C14. AIB $=$ alpha amino isobutyric acid-1-C14.

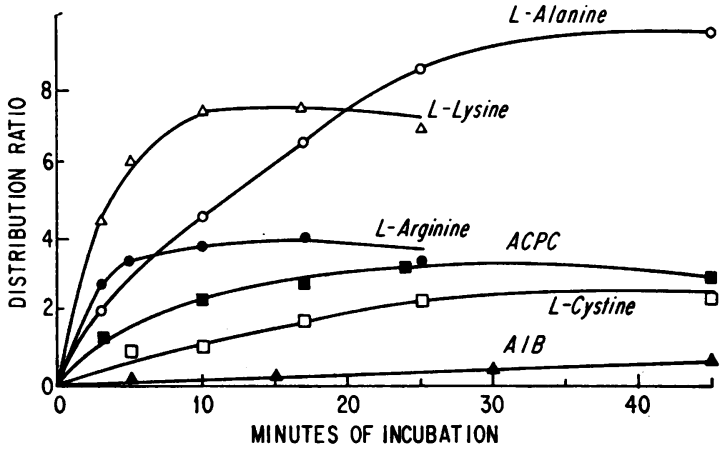

Fig. 3. TIME COURSE OF UPTAKE OF NEUTRAL AND DIBASIC AMINo ACIDS. Substrate concentrations and conditions of incubation were as described in Table II. The curves shown are representative of results obtained in three subjects.

in others cystine was not accumulated by the cells in excess of the concentration in the medium. The time course of amino acid uptake is shown in Figure 3. Steady state conditions (that is influx equal to efflux) were achieved after 25 to 45 minutes of incubation for alanine, ACPC, and cystine and after 10 to 14 minutes for lysine and arginine. AIB uptake increased very slowly with time, but distribution ratios greater than unity were not observed even after 120 minutes of incubation. Addition of 1 to $2 \mathrm{mg}$ glucose per $\mathrm{ml}$ of leukocyte suspension failed to influence uptake of ACPC, glycine, or lysine during 25-minute incubation studies, and therefore, glucose was not added to the incubation medium during subsequent studies, nor was any other external source of energy provided.

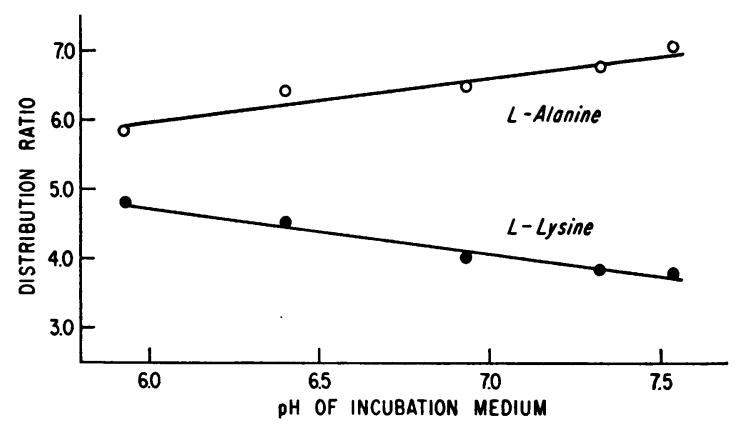

Fig. 4. INFLUENCE OF PH OF INCUBATION MEDIUM ON UPTAKE OF L-ALANINE AND L-LYSINE. These experiments were carried out in Krebs-Ringer phosphate buffers at $37^{\circ} \mathrm{C}$ with 25 -minute incubation periods. Substrate concentrations were as noted in Table II. The distribution ratios represent the mean of three experiments in three subjects. 
TABLE III

Effect of metabolic inhibitors on uptake of amino acids by human leukocytes

\begin{tabular}{lcccc}
\hline \hline & & \multicolumn{2}{c}{$\begin{array}{c}\text { Per cent inhibition } \\
\text { of transport }\end{array}$} \\
\cline { 3 - 5 } \cline { 3 - 4 } Inhibitor & $\begin{array}{c}\text { Inhibitor } \\
\text { concentration }\end{array}$ & ACPC L-Alanine L-Lysine \\
\hline & $M$ & & & \\
CN $^{-}$ & $10^{-2}$ & 0 & 0 & 0 \\
$2,4-D N P^{*}$ & $5 \times 10^{-4}$ & 0 & & 0 \\
Anaerobiosist & & 0 & 0 & \\
F- & $10^{-2}$ & 64 & 38 & 33 \\
Iodoacetamide & $10^{-2}$ & 87 & 91 & 80 \\
Ouabain & $7 \times 10^{-8}$ & & 67 & -37 \\
\hline
\end{tabular}

*2,4-DNP $=2,4$-dinitrophenol.

$\dagger$ Anaerobiosis achieved by incubation of cells in $95 \% \mathrm{~N}_{2}-5 \% \mathrm{CO}_{2}$ Incubation duration was 25 minutes in all experiments. Conditions of incubation were as described in Table II. Values represent mean of observations in three normal subjects.

Effect of incubation medium $p H$ on amino acid uptake. Leukocyte suspensions were incubated in Krebs-Ringer phosphate buffers ranging from $\mathrm{pH} 6$ to $\mathrm{pH}$ 7.6. As shown in Figure 4, uptake of alanine increased slightly as the $\mathrm{pH}$ of the buffer rose, whereas lysine uptake fell as the $\mathrm{pH}$ was increased. The magnitude of the above effects was not great over the $\mathrm{pH}$ range used. All subsequent experiments were carried out at the $\mathrm{pH}$ normally found in blood plasma, 7.4.

Influence of metabolic inhibitors on amino acid uptake. An important criterion of active transport systems is their dependence on energy yielding processes, and this parameter was, hence, investigated in leukocyte suspensions with inhibitors of aerobic and anaerobic glycolysis. In contrast to results obtained in rat kidney cortex (15), human intestinal mucosa (19), or guinea pig lymph node cells (20), uptake of neutral and cationic amino acids was not influenced by anaerobic conditions, cyanide, or 2,4-dinitrophenol (DNP), known inhibitors of oxidative metabolism (Table III). However, sodium fluoride and iodoacetamide, inhibitors of anaerobic glycolysis, were found to reduce markedly accumulation of ACPC, alanine, and lysine.

Dependence of amino acid uptake on sodium concentration of incubation medium. Yunis and associates (5) reported that the uptake of alanine and other neutral amino acids by leukemic leukocytes was markedly influenced by changes in extracellular $\mathrm{Na}^{+}$, whereas lysine uptake was unaffected by medium $\mathrm{Na}^{+}$. Similar studies were carried out in normal leukocytes with completely analogous results. As shown in Figure 5, increasing medium
$\mathrm{Na}^{+}$from 25 to $144 \mathrm{mEq}$ per $\mathrm{L}$ resulted in an almost linear increase in the steady state distribution ratio for alanine and in rising intracellular concentrations of $\mathrm{Na}^{+}$and $\mathrm{K}^{+}$. However, increasing medium $\mathrm{Na}^{+}$concentration from 25 to $108 \mathrm{mEq}$ per $\mathrm{L}$ resulted in no change in lysine uptake, despite changes in tissue $\mathrm{Na}^{+}$and $\mathrm{K}^{+}$that mirrored those observed with alanine. Furthermore, ouabain, a specific inhibitor of the membrane cation pump, was shown to impair alanine uptake but seemed to stimulate lysine accumulation (Table III). As expected, ouabain produced a distinct increase in intracellular $\mathrm{Na}^{+}$and a fall in cell $\mathrm{K}^{+}$, regardless of the amino acid used as substrate.

Application of diffusion and Michaelis-Menten kinetics. It is widely held that amino acid transport in a variety of biological systems is composed of two components: one that obeys Fick's law of physical diffusion and one that is saturable. The former component, which may be either physical diffusion or mediated passage by a site so abundant that it is not saturated over the range of substrate concentrations used (21), is not energy dependent and does not produce uphill transport against a gradient. In the present studies, the up-

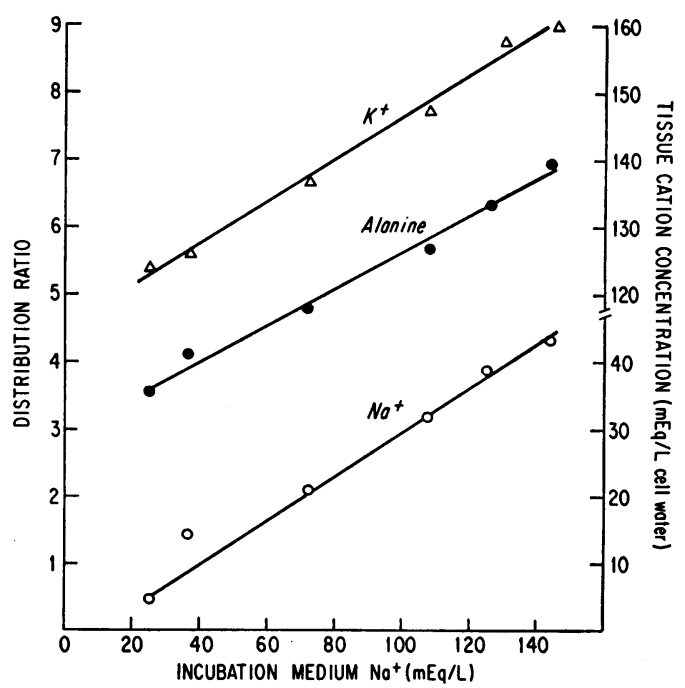

Fig. 5. EFfect of alteration in Medium $\mathrm{NA}^{+} \mathrm{CON}-$ CENTRATION ON UPTAKE OF L-ALANINE AND CELLULAR CONCENTRATIONS OF $\mathrm{NA}^{+}$AND $\mathrm{K}^{+}$. Distribution ratios for alanine are plotted on the left ordinate, and the cation concentrations are presented on the right ordinate. Tris ${ }^{+}$ was substituted for $\mathrm{Na}^{+}$in equimolar fashion. Medium $\mathrm{K}^{+}$was $7.2 \mathrm{mEq}$ per $\mathrm{L}$ throughout. Duration of incubation was 25 minutes at $37^{\circ} \mathrm{C}$.. Values represent results from one of three representative studies. 


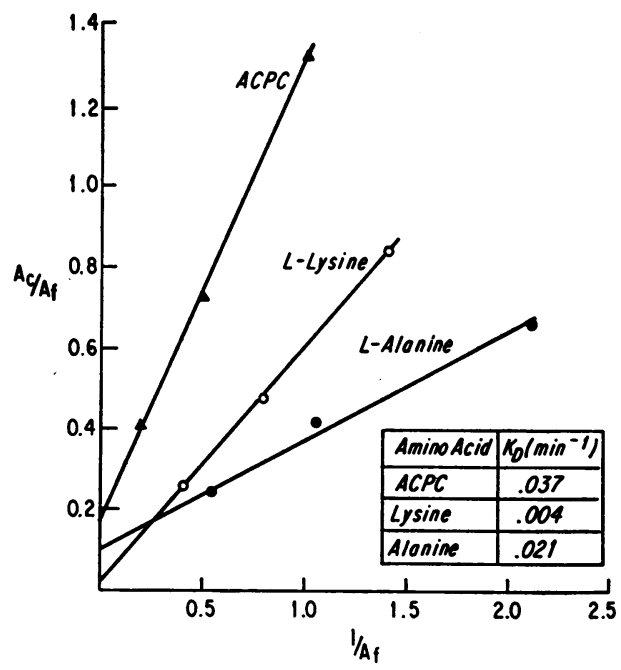

Fig. 6. Distribution ratio for l-alanine, ACPC, AND LYSINE PLOTTED AGAINST RECIPROCAL OF MEDIUM SUBSTRATE CONCENTRATION ( $A_{f}$ ), EXPRESSED IN MILLIMOLES PER LITER. Ac $=$ intracellular substrate concentration. From extrapolation of curves to infinite substrate concentration, values for apparent diffusion constant, $K_{D}$ $\left(\min ^{-1}\right)$, were calculated. See text for details.

take of glycine, AIB, and glutamic acid (Table II and Figure 3 ) can be explained by such a process. To determine whether the observed uphill transport of alanine, ACPC, lysine, and arginine was associated with the presence of saturable binding sites, the following studies were undertaken.

In the mathematical analysis to follow, the formulation of Akedo and Christensen will be used (21). The following equation represents the sum of the two transport components mentioned above:

$$
\frac{d A_{c}}{d t}=Y+K_{D}\left(A_{f}-A_{c}\right),
$$

where $A_{c}$ is the intracellular substrate concentration; $\mathrm{Y}$ the uptake velocity due to the saturable mechanism; $K_{\mathbf{D}}$ the apparent diffusion constant, and $A_{f}$ the extracellular substrate concentration. Integration of Equation 2 yields

$$
\frac{A_{c}}{A_{f}}=\frac{Y}{K_{D}}\left(1-e^{-K_{D^{t}}}\right) \frac{1}{A_{f}}+\left(1-e^{-K_{D^{t}}}\right) .
$$

If the extracellular substrate concentration is sufficiently high, $\mathrm{Y}$, being saturated, will be virtually constant. It then follows that the ordinate intercept of the straight line relating $1 / \mathrm{A}_{\mathrm{f}}$ to the distribution ratio $\left(\mathrm{A}_{c} / \mathrm{A}_{f}\right)$ yields the quantity $\left(1-\mathrm{e}^{-\mathbf{K}_{\mathbf{D}} \mathbf{t}}\right)$, from which $\mathrm{K}_{\mathbf{D}}$ may be estimated.
In these studies, cells were incubated for 5 minutes to utilize the linear portion of the uptake curve during which velocity is maximal. As shown in Figure 6 , the plot of $1 / A_{f}$ versus $A_{c} / A_{f}$ for alanine, ACPC, and lysine gives ordinate intercepts ranging from 0.02 for lysine to 0.17 for ACPC. These values were then used to calculate $K_{D}$ and subsequently $\mathrm{Y}$ by substituting into Equation 3 .

If the saturable portion of the transport process is thought of as a reaction conforming to the Michaelis-Menten equation, $\mathrm{Y}$ is given by the following expression :

$$
\mathrm{Y}=\frac{V_{\max } A_{f}}{K_{m}+A_{f}} .
$$

The applicability of Equation 4 to amino acid uptake by leukocytes was investigated over a 10 - to 20 -fold range of extracellular substrate concentrations. The data showed that as the extracellular concentrations of ACPC, alanine, lysine, and arginine were increased, the intracellular concentration approached a constant value, indicating saturation. When these data were plotted according to the double reciprocal method of Lineweaver and Burk as seen in Figure 7, straight lines with positive ordinate intercepts were obtained from which values for $\mathrm{V}_{\max }$ and $\mathrm{K}$ were calculated. The values for $K_{m}$ ranged from 0.05 mmole per $L$ for

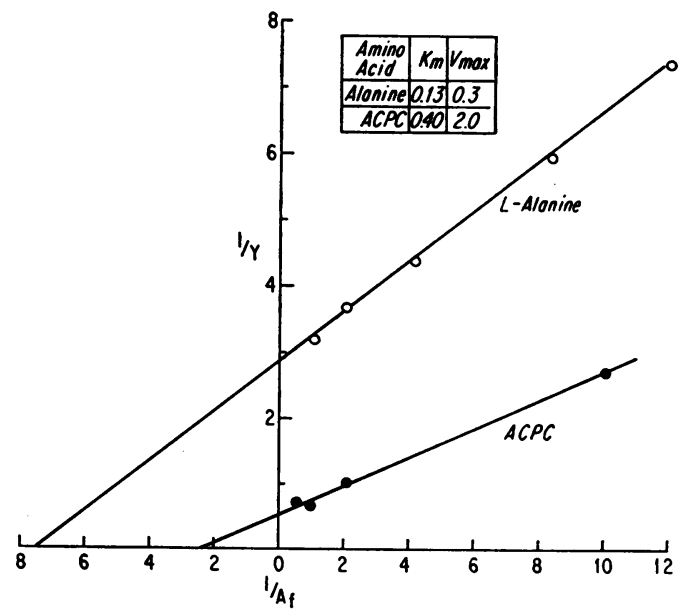

Fig. 7. EFFect of alteration of MEdium substrate CONCENTRATION, At (MILlimoles PER LITER), ON THE SATURABLE TRANSFER PROCESS, Y (MILLIMOLES PER LITER PER 5 MINUTES). Results are plotted according to the double reciprocal method of Lineweaver and Burk. Values for $K_{m}$ and $V_{\max }$ were calculated from abscissa and ordinate intercepts, respectively. 
TABLE IV

Inhibition of uptake of L-arginine, L-lysine, or L-cystine by second dibasic amino acids*

\begin{tabular}{|c|c|c|c|}
\hline $\begin{array}{l}\text { Substrate con- } \\
\text { centration }\end{array}$ & Inhibitor & $\begin{array}{l}\text { Inhibitor } \\
\text { concen- } \\
\text { tration }\end{array}$ & $\% \underset{\text { tiont }}{\text { Inhibi- }}$ \\
\hline$m M$ & & $m M$ & \\
\hline \multirow[t]{10}{*}{ L-Lysine (0.05) } & L-Arginine & 0.05 & 40 \\
\hline & & 0.10 & 46 \\
\hline & & 0.20 & 55 \\
\hline & & 0.30 & 65 \\
\hline & & 0.60 & 78 \\
\hline & & 2.40 & 93 \\
\hline & L-Ornithine & 0.05 & 35 \\
\hline & & 0.30 & 61 \\
\hline & L-Cystine & 0.40 & $4 \ddagger$ \\
\hline & & 2.40 & $12 \ddagger$ \\
\hline \multirow[t]{4}{*}{ L-Arginine $(0.05)$} & L-Lysine & 0.08 & 38 \\
\hline & & 0.30 & 57 \\
\hline & L-Ornithine & 0.05 & 24 \\
\hline & & 0.10 & 76 \\
\hline \multirow[t]{5}{*}{ L-Cystine (0.04) } & L-Arginine & 0.10 & 0 \\
\hline & & 0.20 & $\mathbf{0}$ \\
\hline & & 0.60 & 0 \\
\hline & & 1.00 & 0 \\
\hline & & 2.40 & $6 t$ \\
\hline
\end{tabular}

* Duration of incubation was 5 minutes for all experiments except those in which cystine was used either as substrate or inhibitor, in which those in which cystine was used either as substrate or

t Values obtained from mean of duplicate determinations in two to four normal subjects.

Not statistically significant $(p>0.4)$

arginine to 0.4 mmole per $\mathrm{L}$ for ACPC. These results are in the range previously reported by Helmreich and Kipnis (20) for AIB uptake by isolated lymph node cells.

Failure to demonstrate competition between cystine and the dibasic amino acids. The studies described above indicated that uptake of neutral and dibasic amino acids by normal leukocytes is accomplished by saturable mechanisms that conform to Michaelis-Menten kinetics. It therefore follows that a group of amino acids transported

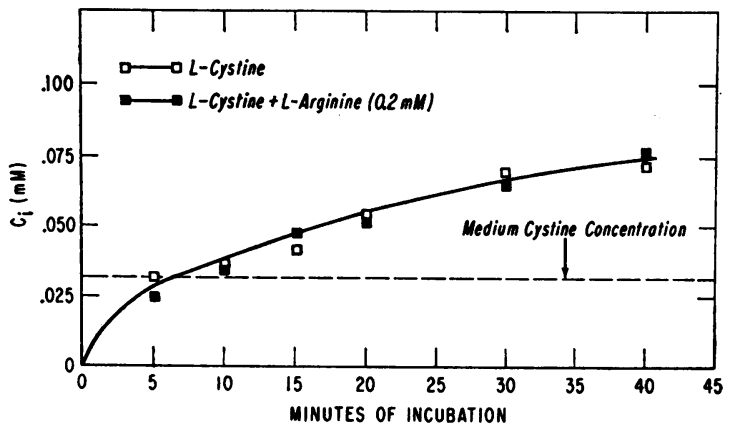

Fig. 8. TIME course OF L-CYSTINe UPTAKE IN PRESENCE AND ABSENCE OF L-ARGININE (0.2 $\mathrm{MM})$. The intracellular cystine concentration $\left(C_{1}\right)$ was not significantly affected by arginine at any time point.
TABLE V

Effect of ouabain $\left(7 \times 10^{-4} \mathrm{M}\right)$ on uptake of L-lysine, L-arginine, or L-cystine*

\begin{tabular}{|c|c|c|}
\hline \multirow[b]{2}{*}{ Substrate } & \multicolumn{2}{|c|}{ Distribution ratio } \\
\hline & Control & Ouabain \\
\hline $\begin{array}{l}\text { L-Lysine } \\
\text { L-Arginine } \\
\text { L-Cystine }\end{array}$ & $\begin{array}{l}2.98(2.1-4.1) \\
2.05(1.4-2.8) \\
0.80(0.5-1.0)\end{array}$ & $\begin{array}{l}4.13(3.4-4.9) \\
3.07(2.0-4.1) \\
0.58(0.2-0.7)\end{array}$ \\
\hline
\end{tabular}

* Leukocytes were preincubated at $37^{\circ} \mathrm{C}$ for 15 minutes with ouabain before addition of amino acid. Then, 25minute incubation studies were performed. Values represent mean and range of duplicate determinations in three normal subjects. Ouabain produced an increase in uptake of lysine and arginine and a decrease in uptake of cystine in each subject.

by a common mechanism (or carrier) should be mutually competitive. This postulate was examined for the dibasic amino acids and cystine. Lysine, arginine, and ornithine were mutually inhibitory (Table IV), even in equimolar concentrations. Cystine, however, did not inhibit the uptake of lysine or arginine, nor was its uptake influenced by the other dibasic amino acids (Table IV). Since the rate of cystine uptake was much slower than that of lysine or arginine, it seemed possible that the 5-minute incubation duration was too short for studies in which cystine was used as substrate or inhibitor. However, as shown in Figure 8 , cystine uptake during 5- to 45-minute incubation periods was not influenced by $0.2 \mathrm{mM}$ arginine, a concentration large enough to markedly inhibit lysine uptake. Similar negative results were obtained when unlabeled cystine was used as an inhibitor of arginine transport during 5- to 25-

TABLE VI

Saturable nature of cystine uptake by normal human leukocytes*

\begin{tabular}{|c|c|c|c|}
\hline \multirow[b]{2}{*}{ Subject } & \multicolumn{2}{|c|}{$\begin{array}{c}\text { L-Cystine-Sas concen- } \\
\text { tration }\end{array}$} & \multirow{2}{*}{$\begin{array}{c}\text { Distri- } \\
\text { bution } \\
\text { ratio }\end{array}$} \\
\hline & Medium & $\begin{array}{l}\text { Intracellu- } \\
\text { larifluid }\end{array}$ & \\
\hline & \multicolumn{2}{|c|}{$m M$} & \\
\hline 1 & $\begin{array}{l}0.012 \\
0.024 \\
0.048 \\
0.096\end{array}$ & $\begin{array}{l}0.027 \\
0.041 \\
0.055 \\
0.075\end{array}$ & $\begin{array}{l}2.25 \\
1.71 \\
1.14 \\
0.78\end{array}$ \\
\hline 2 & $\begin{array}{l}0.007 \\
0.012 \\
0.024 \\
0.096\end{array}$ & $\begin{array}{l}0.009 \\
0.014 \\
0.024 \\
0.040\end{array}$ & $\begin{array}{l}1.24 \\
1.20 \\
1.00 \\
0.42\end{array}$ \\
\hline
\end{tabular}

* Cells were incubated for 25 minutes as described in Table II. 
minute studies. An additional difference between the transport systems for cystine and the dibasic amino acids was demonstrated with ouabain. The data in Table $\mathrm{V}$ indicate that, as noted previously, ouabain $\left(7 \times 10^{-4} \mathrm{M}\right)$ did not inhibit lysine or arginine transport during 25-minute studies (the distribution ratios actually being higher in the presence of the glycoside). In contrast, cystine uptake was reproducibly decreased by ouabain.

Since cells from many subjects failed to accumulate cystine in excess of the concentration in the incubation medium, it could be argued that cystine entered the leukocytes by physical diffusion only. To test this hypothesis, normal leukocytes

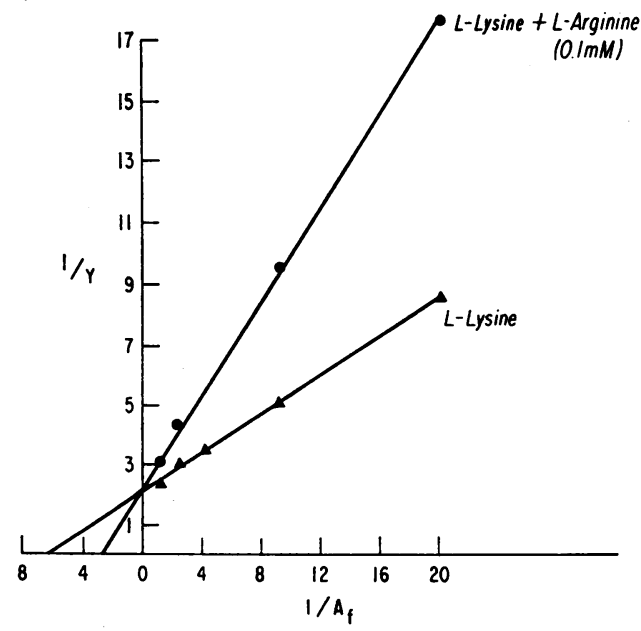

Fig. 9. Double ReCIPROCAL PLOT OF L-LYSINE UPTAKE IN PRESENCE AND ABSENCE OF L-ARGININE. $A_{f}$ and $Y$ as defined in Figure 7 and in text. Common ordinate intercept indicates competitive inhibition. Values of $K_{m}$, $K_{1}$, and $V_{\max }$ from these data are shown in Table VII.

were incubated with increasing concentrations of L-cystine for 25 minutes. As shown in Table VI, cells from each of two subjects showed a fall in the cystine distribution ratio as the medium concentration was increased, and the labeled cystine concentration in cell water appeared to be leveling off at the highest medium concentrations employed. These findings were apparent in Subject 2, in whom distribution ratios in excess of unity were never observed, as well as in Subject 1. Similar results were obtained from two other normal subjects and indicate that the uptake process for cystine in the leukocyte is not simple diffusion, but rather follows the behavior of a mediated system.

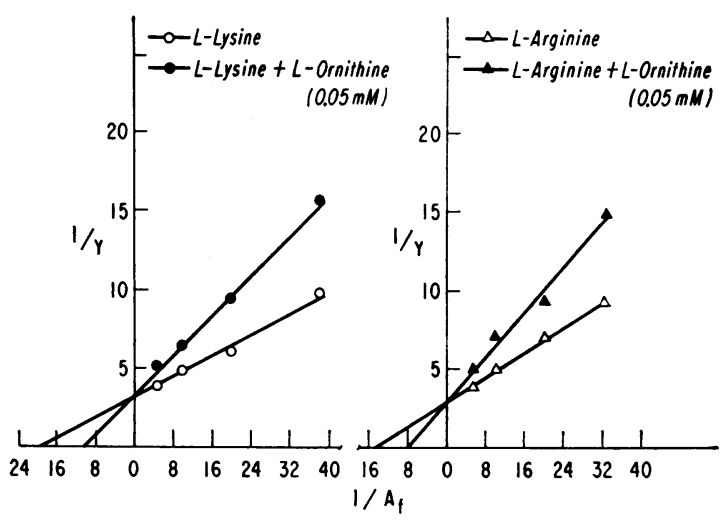

Fig. 10. Double Reciprocal plot of L-Lysine AND L-ARGININE UPTAKE IN PRESENCE OF L-ORNITHINE. Common ordinate intercept indicates competitive inhibition of both amino acids by ornithine. See Table VII for calculation of $K_{1}$ ornithine when either lysine or arginine was used as substrate. $A_{1}$ and $Y$ as defined in Figure 7.

Kinetic analysis of competition between lysine, arginine, and ornithine. Ahmed and Scholefield (22) and, more recently, Scriver and Wilson (23) have proposed that if several substances $(A, B, C)$ share an identical transport mechanism, the following observations must hold: 1) $A, B$, and $C$ must be mutually competitive; 2 ) the $\mathrm{K}_{\mathrm{m}}$ for $A$ as a substrate should equal its inhibitory constant $\left(\mathrm{K}_{\mathbf{i}}\right)$ when directed against $B$ and vice versa; and 3 ) the $\mathrm{K}_{\mathbf{1}}$ for substance $C$ should be the same when used as an inhibitor of either $A$ or $B$.

Lysine, arginine, and ornithine were subjected to this analysis with the following results. When lysine uptake was determined in the presence of arginine, the plots shown in Figure 9 were obtained. These data show that as the concentration of lysine was increased, the inhibition by arginine was partially overcome. The common ordinate in-

TABLE VII

Estimation of $K_{m}, K_{i}$, and $V_{\max }$ for dibasic amino acids*

\begin{tabular}{lccc}
\hline \hline Amino acid & $\mathrm{K}_{\mathrm{m}}$ & $\mathrm{K}_{\mathrm{i}} \dagger$ & $\mathrm{V}_{\max }$ \\
\hline & $m M$ & $m M$ & $m$ moles $/ L / 5 \min$ \\
L-Lysine & $0.09 \pm 0.03(6)$ & $0.08(2)$ & $0.42 \pm 0.02(6)$ \\
L-Arginine & $0.05 \pm 0.01(5)$ & $0.06 \ddagger(2)$ & $0.30 \pm 0.04(5)$ \\
L-Ornithine & & $0.06 \ddagger(2)$ & \\
& & $0.07 \S(2)$ &
\end{tabular}

* Values for $\mathrm{K}_{\mathrm{m}}, \mathrm{K}_{\mathrm{i}}$, and $\mathrm{V}_{\max }$ represent mean $\pm 1 \mathrm{SD}$ (where shown). Numbers in parentheses refer to number of subjects studied. All values were obtained from 5-minute incubation studies at pH 7.4 in Tris-

modified Krebs-Ringer bicarbonate buffer at $37^{\circ} \mathrm{C}$.
$\dagger$ Estimated from $\mathrm{K}_{\mathrm{i}}=\mathrm{i} /\left(\mathrm{K}_{\mathrm{p}} / \mathrm{K}_{\mathrm{s}}-1\right)$, where $\mathrm{i}=$ concentration of inhibitor, $K_{p}=$ apparent $K_{s}$ in presence of inhibitor (24).

f L-Lysine was substrate. 
TABLE VIII

Uptake of L-lysine, L-arginine, and L-cystine by leukocytes from normal and cystinuric subjects*

\begin{tabular}{lccc}
\hline \hline & \multicolumn{3}{c}{ Distribution ratio } \\
\cline { 2 - 4 } Subjects & Lysine & Arginine & Cystine \\
\hline $\begin{array}{l}\text { Normals } \\
\text { Cystinurics }\end{array}$ & $3.57 \pm 1.51(14)$ & $4.43 \pm 1.27(6)$ & $1.02 \pm 0.40(20)$ \\
$\begin{array}{l}\text { Significance of } \\
\text { difference between } \\
\text { two groups }\end{array}$ & $4.21 \pm 1.72(5)$ & $4.93 \pm 1.85(7)$ & $0.75 \pm 0.41(8)$ \\
& $0.5>\mathrm{p}>0.4$ & $0.6>\mathrm{p}>0.4$ & $0.2>\mathrm{p}>0.1$ \\
\hline
\end{tabular}

* The initial incubation medium concentrations of the amino acids were as follows: L-lysine, $0.05 \mathrm{mmole}$ per L; $\mathrm{L}$-arginine, $0.06 \mathrm{mmole}$ per $\mathrm{L}$; L-cystine, $0.04 \mathrm{mmole}$ per $\mathrm{L}$. Each determination was performed in duplicate, and the values represent the mean $\pm 1 \mathrm{SD}$. The values in parentheses indicate the number of subjects studied. All incubations were carried out in Tris-modified Krebs-Ringer bicarbonate buffer, $\mathrm{pH} 7.4$, at $37^{\circ} \mathrm{C}$ for 25 minutes.

$\dagger$ Defined as the ratio of the labeled amino acid concentration (counts per minute per milliliter) in the intracellular fluid to that in the incubation medium.

tercept for the two plots indicates competitive inhibition between lysine and arginine. As shown in Figure 10, completely analogous results were obtained when ornithine was used as an inhibitor of either lysine or arginine. Similarly, lysine competitively inhibited arginine uptake (not shown). Hence, requirement 1 is satisfied. As noted in Table VII, the $K_{m}$ and $K_{i}$ values for arginine and lysine, respectively, are in good agreement, thus satisfying requirement 2 . To study requirement 3 , ornithine was used as an inhibitor of lysine and arginine uptake, and as shown in Table VII, virtually identical $K_{i}$ values were obtained regardless of substrate. Thus, all of the above mentioned criteria for a single site interaction were satisfied by these three amino acids.

Uptake of dibasic amino acids and cystine by leukocytes from cystinuric subjects. No significant differences in steady state uptake of lysine, arginine, or cystine were found in cells from cystinuric subjects when compared with controls ( $\mathrm{Ta}$ ble VIII). Furthermore, the time course of uptake of these amino acids was not different in the two populations. These results suggested that no transport defect exists in leukocytes in cystinuria, and this conclusion was strengthened by two other groups of observations. First, as with normal cells, arginine $(0.2 \mathrm{mM})$ markedly reduced lysine uptake by cells from two cystinuric subjects ( 59 and $65 \%$ inhibition, respectively). Finally, the $\mathrm{K}_{\mathrm{m}}$ for lysine in cells from one patient with cystinuria was found to be $0.11 \mathrm{mmole}$ per L-in good agreement with the mean value of 0.09 mmole per $\mathrm{L}$ obtained in normal subjects (Table VII).

\section{Discussion}

The failure of inhibitors of oxidative metabolism to influence amino acid uptake by leukocytes suggests that the energy required for the uphill transport observed is derived from anaerobic pathways. This suggestion is strengthened by the distinct inhibition of amino acid uptake caused by fluoride or iodoacetamide, known inhibitors of anaerobic glycolysis. It should be pointed out, however, that whereas fluoride appears to be a specific inhibitor of anaerobic glycolysis, iodoacetamide acts by binding free sulfhydryl groups, and could, therefore, affect reactions other than those involved in glycolysis, such as the orientation or availability of free sulfhydryl groups in the cell membrane, which might be important in binding or penetration of amino acids.

The present results agree well with those obtained by Yunis and his colleagues (5) using leukemic leukocytes. In both normal and malignant cells, transport of many neutral amino acids is dependent on medium $\mathrm{Na}^{+}$concentration, but that of the dibasic amino acids is not. As expected, ouabain inhibited the uptake of those amino acids that were $\mathrm{Na}^{+}$-dependent, but actually appeared to stimulate lysine and arginine accumulation. It seems likely that ouabain, by inhibiting $\mathrm{K}^{+}$influx, facilitates the entry of the cationic amino acids because of their net positive charge, rather than by accelerating the influx mediated by the specific dibasic amino acid carrier system. Indeed, the net stimulation of lysine and arginine uptake in the presence of ouabain could hide an inhibitory action of the glycoside that was of smaller magnitude.

It is of interest that glycine and AIB, which are 
concentrated by leukemic leukocytes (5), were not accumulated against chemical gradients by normal cells. Although it is possible that this discrepancy represents differences in technique of cell preparation or incubation, the similarity of results with other amino acids in the two studies suggests that the differences may be real. This discussion can be settled only by carrying out experiments with malignant and normal cells in a single laboratory.

These studies indicate that membrane transport of the dibasic amino acids is not defective in all tissues in cystinuria. Steady state uptake of lysine, arginine, and cystine by leukocytes from cystinuric subjects did not differ significantly from that observed in normal subjects. Furthermore, in leukocytes from cystinuric as well as normal subjects, lysine and arginine competed for a common transport process that was saturable and conformed to Michaelis-Menten kinetics. The close agreement between the estimated affinity constants $\left(\mathrm{K}_{\mathrm{m}}\right)$ for lysine uptake by normal and cystinuric cells provides additional evidence that the transport process(es) for the dibasic amino acids is fundamentally similar in leukocytes from normal subjects and patients with cystinuria. These results are in accord with those of Becker and Green (25), who incubated peripheral leukocytes from two cystinuric and control subjects with lysine- $\mathrm{C}^{14}$ and cystine- $\mathrm{S}^{35}$. These workers did not measure the free cellular amino acid content, but rather found that the trichloroacetic acid precipitable $C^{14}$ or $S^{35}$ content of the leukocytes was the same in the two groups. It is quite possible that, related to their distinct anatomic and physiologic similarity, only the gut and kidney have transport mechanisms that are altered in cystinuria, but this conclusion must await future studies in other human tissues.

Analysis of data obtained from studies of the transport of cystine and the dibasic amino acids in human gut, kidney, and leukocytes reveals a most complex situation. Lysine, arginine, and ornithine have been found to share a common transport mechanism in all three tissues, but there is evidence that even this common mechanism is not the same in the three tissues studied. The values for $\mathrm{K}_{\mathrm{m}}$ and $\mathrm{V}_{\max }$ for lysine in the kidney and gut were 2 to 5 mmoles per $\mathrm{L}$ and 0.5 to 0.8 mmole per L per minute, respectively $(1,2)$, in marked contrast to values in the leukocytes: $\mathrm{K}_{\mathrm{m}}$, 0.09 mmole per $\mathrm{L} ; \mathrm{V}_{\max }, 0.06$ mmole per $\mathrm{L}$ per minute. These results differ by more than an order of magnitude and suggest the presence of either qualitative or quantitative dissimilarities in the interaction between lysine and its postulated carrier system in the tissues studied. The tissue specificity for these amino acids becomes even more striking when cystine uptake is examined, in that cystine competes for transport sites with lysine and arginine in jejunal mucosa but not in kidney cortex or leukocytes.

There is ample precedent in man for the concept that an inherited disease need not be associated with metabolic defects in all tissues. Only a few examples will be cited. X-linked glucose-6phosphate dehydrogenase deficiency has been reported in red blood cells but not in leukocytes (26). Some patients with galactosemia can oxidize galactose to carbon dioxide in the liver but not in skin, leukocytes, intestine, or red blood cells (27). Glycogenosis due to debranching enzyme deficiency may be localized to either muscle or liver (28). Finally, porphyrin biosynthesis is altered in the liver but not the bone marrow in acute intermittent porphyria (29), whereas the reverse situation exists in erythropoietic porphyria (29).

It is, of course, a truism that the expression of the genetic information presumably common to all cells varies from tissue to tissue. Thus, only erythrocyte precursors make hemoglobin, and certain enzymes such as phenylalanine hydroxylase are found only in the liver. Furthermore, the evidence from the study of hereditary diseases just cited would indicate that enzymes which carry out the same or similar functions are not identical in all tissues, or at least, are not under identical mechanisms of genetic control. Indeed, situations are known in which more than one enzyme capable of catalyzing a given function is present in the same cell. Thus, erythrocytes contain at least two carbonic anhydrase species (30), and Salmonella typhimurium has been shown to possess two histidine permease systems (31).

With this type of evidence, it does not seem unreasonable to postulate the existence of more than one type of transport system for the dibasic amino acids, each system being under separate genetic control. One system, common to the renal tubule and intestinal mucosa, is affected in cys- 
tinuria. Another, present in the leukocyte, is spared. Examination of this hypothesis must await a molecular definition of the mechanisms responsible for mediated transport and defects thereof.

Finally, the limitations encountered in the use of leukocyte suspensions for in vitro study should be pointed out. Because of the low peripheral leukocyte count found in normal subjects, volumes of less than $100 \mathrm{ml}$ of blood provide too few cells for satisfactory suspensions. This shortcoming could perhaps be circumvented by producing a leukocytosis with endotoxin or other stimulus. Secondly, the suspensions consist of granulocytes, lymphocytes, and monocytes rather than a single cell type. Since one of the aims of these experiments was to allow study of transport properties in various inherited and acquired metabolic disorders, it did not seem feasible to complicate further the already time-consuming and tedious isolation procedure. Lastly, it seems likely that certain quantitative aspects of amino acid transport are altered by the numerous steps needed for isolation of relatively uncontaminated leukocyte preparations and by their incubation in media that do not contain protein, other amino acids, hormones, and the myriad of metabolites normally present in plasma. However, results to date suggest that the leukocytes as used retain important morphologic and physiologic characteristics that justify their use as an additional tool for studies of membrane transport phenomena in man.

\section{Summary}

1. Leukocyte suspensions, prepared from peripheral blood of normal volunteers by dextran sedimentation and hypotonic erythrocyte lysis, were noted to transport neutral and dibasic amino acids against chemical gradients in vitro by processes that are saturable and are dependent on energy generated by anaerobic glycolysis.

2. Studies with ouabain and with reduced medium $\mathrm{Na}^{+}$concentration indicated that the transport of alanine and cystine but not of lysine and arginine depends on a functioning membrane cation transport mechanism or critical transmembrane concentrations of sodium and potassium, or on both.
3. Lysine, arginine, and ornithine shared a single transport system not utilized by cystine. Kinetic analysis suggested that this common transport mechanism differs from that in gut and kidney.

4. No defect in the transport of the dibasic amino acids or cystine was found in leukocytes from cystinuric subjects. The complexities apparent in studies of dibasic amino acid transport in several human tissues and their possible genetic control mechanisms are discussed.

\section{References}

1. Perry, S. Biochemistry of the white blood cell. J. Amer. med. Ass. 1964, 190, 918.

2. Nour-Eldin, F., and J. F. Wilkinson. Amino acid content of white blood cells in human leukaemias. Brit. J. Haemat. 1955, 1, 358.

3. Iyer, G. Y. N. Free amino acids in leukocytes from normal and leukemic subjects. J. Lab. clin. Med. 1959, 54, 229.

4. McMenamy, R. H., C. C. Lund, G. J. Neville, and D. F. H. Wallach. Studies of unbound amino acid distributions in plasma, erythrocytes, leukocytes and urine of normal human subjects. J. clin. Invest. $1960,39,1675$.

5. Yunis, A. A., G. K. Arimura, and D. M. Kipnis. Amino acid transport in blood cells. I. Effect of cations on amino acid transport in human leukocytes. J. Lab. clin. Med. 1963, 62, 465.

6. Valentine, W. N. The metabolism of the leukemic leukocyte. Amer. J. Med. 1960, 28, 699.

7. Fox, M., S. Thier, L. E. Rosenberg, W. Kiser, and S. Segal. Evidence against a single renal transport defect in cystinuria. New Engl. J. Med. 1964, 270, 556.

8. Thier, S., M. Fox, S. Segal, and L. E. Rosenberg. Cystinuria: in vitro demonstration of an intestinal transport defect. Science 1964, 143, 482.

9. McCarthy, C. F., J. L. Borland, Jr., H. J. Lynch, Jr., E. E. Owen, and M. P. Tyor. Defective uptake of basic amino acids and L-cystine by intestinal mucosa of patients with cystinuria. J. clin. Invest. 1964, 43, 1518.

10. Rosenberg, L. E., and S. J. Downing. Transport of cystine and the dibasic amino acids by leukocytes from normal subjects and patients with cystinuria. J. clin. Invest. 1964, 43, 1290.

11. Skoog, W. A., and W. S. Beck. Studies on the fibrinogen, dextran and phytohemagglutinin methods of isolating leukocytes. Blood 1956, 11, 436.

12. Fallon, H. J., E. Frei III, J. D. Davidson, J. S. Trier, and D. Burk. Leukocyte preparations from human blood: evaluation of their morphologic and metabolic state. J. Lab. clin. Med. 1962, 59, 779.

13. Manchester, K. L., and F. G. Young. The effect of insulin in vitro on the accumulation of amino acids 
by isolated rat diaphragm. Biochem. J. 1960, 75, 487.

14. Steinberg, D., M. Vaughan, C. B. Anfinsen, J. D. Gorry, and J. Logan. The preparation of tritiated proteins by the Wilzbach method and a simple method for liquid scintillation counting of radioactive proteins in Liquid Scintillation Counting, C. G. Bell, Jr., and F. Newton Hayes, Eds. New York, Pergamon, 1958, p. 230.

15. Rosenberg, L. E., A. Blair, and S. Segal. Transport of amino acids by slices of rat-kidney cortex. Biochim. biophys. Acta (Amst.) 1961, 54, 479.

16. Schrek, $R$. In vitro studies on the physiology of cells. Interactions of thymic cells and an oxidation-reduction indicator, 2,6-dichlorophenalindophenol. Arch. Path. 1946, 42, 163.

17. Eisen, H. N., M. Kern, W. T. Newton, and E. Helmreich. A study of the distribution of 2,4-dinitrobenzene sensitizers between isolated lymph node cells and extracellular medium in relation to induction of contact skin sensitivity. J. exp. Med. 1959, 110, 187.

18. Akedo, H., and H. N. Christensen. Transfer of amino acids across the intestine: a new model amino acid. J. biol. Chem. 1962, 237, 113.

19. Thier, S. O., S. Segal, M. Fox, A Blair, and L. E. Rosenberg. Cystinuria: defective intestinal transport of dibasic amino acids and cystine. J. clin. Invest. 1965, 44, 442.

20. Helmreich, E., and D. M. Kipnis. Amino acid transport in lymph node cells. J. biol. Chem. 1962, 237, 2582.

21. Akedo, H., and H. N. Christensen. Nature of insulin action on amino acid uptake by the isolated diaphragm. J. biol. Chem. 1962, 237, 118.
22. Ahmed, K., and P. G. Scholefield. Biochemical studies on 1-aminocyclopentane carboxylic acid. Canad. J. Biochem. 1962, 40, 1101.

23. Scriver, C. R., and O. H. Wilson. Possible locations for a common gene product in membrane transport of imino acids and glycine. Nature (Lond.) 1964, 202, 92.

24. Dixon, M., and E. C. Webb. Enzyme inhibitors in Enzymes. New York, Academic Press, 1964, p. 327.

25. Becker, F. F., and H. Green. Incorporation of cystine and lysine by normal and "cystinuric" leukocytes. Proc. Soc. exp. Biol. (N. Y.) 1958, 99, 694.

26. Marks, P. A., J. Banks, and R. T. Gross. Genetic heterogeneity of glucose-6-phosphate dehydrogenase deficiency. Nature (Lond.) 1962, 194, 454.

27. Topper, Y. J., L. Laster, and S. Segal. Galactose metabolism: phenotypic differences among tissues of a patient with congenital galactosemia. $\mathrm{Na}$ ture (Lond.) 1962, 196, 1006.

28. Hers, H. G. Glycogen storage disease in Advances in Metabolic Disorders, R. Levine and R. Luft, Eds. New York, Academic Press, 1964, vol. 1, p. 2.

29. Schmid, R. The porphyrias in The Metabolic Basis of Inherited Disease, J. B. Stanbury, J. B. Wyngaarden, and D. S. Fredrickson, Eds. New York, McGraw-Hill, 1960, p. 939.

30. Rieder, R. F., and D. J. Weatherall. A variation in the electrophoretic pattern of human erythrocyte carbonic anhydrase. Nature (Lond.) 1964, 203, 1364.

31. Ames, G. F. Uptake of amino acids by Salmonella typhimurium: Arch. Biochem. 1964, 104, 1. 